${ }^{1}$ Северо-Осетинская
государственная
медицинская академия

${ }^{2}$ Институт

биомедицинских

исследований

Владикавказского

научного иентра

Российской

академии наук

Республика Северная

Осетия - Алания,

Владикавказ

\section{Первичный иммунодефицит}

\section{гуморального звена иммунитета - болезнь Брутона у шестилетнего ребенка (клинический случай)}

\author{
Т.Б. Касохов, д.м.н., проф., ${ }^{1,}$, З.А. Цораева, к.м.н. ${ }^{1}$, А.И. Мазур ${ }^{1}$, \\ С.В. Туриева, к.м.н. ${ }^{1}$, А.А. Царева ${ }^{1}$, А.В. Алборова ${ }^{1}$, А.З. Рамонова ${ }^{1}$
}

Адрес для переписки: Тимофей Борисович Касохов, kasohov@mail.ru

Для цитирования: Касохов Т.Б., Цораева З.А., Мазур А.И. и др. Первичный иммунодефицит гуморального звена иммунитета болезнь Брутона у шестилетнего ребенка (клинический случай) // Эффективная фармакотерапия. 2019. Т. 15. № 40. С. 16-19.

Первичный иммунодебицит представляет значимую проблему

здравоохранения. Этим, в частности, обусловлено создание по инициативе ряда стран Европейского регистра пациентов с первичными наследственными иммунодефицитными состояниями и генных мутаций как причин первичной иммунной недостаточности. В детском возрасте заболевание чаще встречается у мальчиков, во взрослом - выявляется с одинаковой частотой у тии, обоего пола.

В статье рассмотрен клинический случай в отношении шестилетнего мальчика с болезнью Брутона. Болезнь Брутона (агаммаглобулинемия) очень редкое (соотночение новорожденных мальчиков 1:1000000)

Х-сиепленное наследственное заболевание, которое ассоциируется смутацией гена изитоплазматической тирозинкиназы (Btk), обеспечивающей дифбереницровку пре-В-лимбоцитов. Данная патология характеризуется агрессивным течением. В отсутствие адекватной терапии возможен летальный исход.

Ключевые слова: болезнь Брутона, иммунитет, иммунодефииит, иммуноглобулины, гуморальное звено

\section{Введение}

Первичные иммунодефицитные состояния, или первичные иммунодефициты, как правило, наследуемые дефекты. Однако в настоящее время встречаются врожденные иммунодефициты, которые в большинстве случаев не наследуются.
Концепция первичных иммунодефицитных состояний сложилась в середине ХХ в. Однако клинические примеры данных патологий описывали и ранее.

Первичные иммунодефицитные состояния очень часто становятся причиной летального ис- хода пациентов моложе 20 лет. Основной причиной такового является присоединение вторичной инфекции. Дети до года, как правило, умирают из-за сепсиса, развившегося на фоне первичного иммунодефицита $[1,2]$.

В основе развития первичных иммунодефицитных состояний лежат мутация генов и перестройка хромосом. Ген, в котором есть дефект, является высоко пенетрантным при условии ранней экспрессии генетического дефекта [2-5].

Рассматриваемые иммунологические поражения можно получить с помощью генно-инженерных технологий нокаута генов. Это позволяет установить связь определенных генов с комплексом структур, которые они детерминируют, и процессами в иммунной системе. Рецессивные мутации, которые локализуются в X-хромосоме, одна из самых частых причин развития первичных иммунодефицитных состояний [6-9].

Х-сцепленное наследственное заболевание - болезнь Брутона, или первичный иммунодефицит гуморального звена иммунитета, впервые был описан в 1954 г. [2, 
$4,5,10-13]$. Причиной его развития является дефект В-клеточной тирозинкиназы (Btk). Последняя участвует в формировании В-лимфоцитов. Как следствие, снижается уровень всех иммуноглобулинов (Ig). Важно отметить, что количество сывороточных иммуноглобулинов, указывающее на функцию В-клеток, а также на их взаимодействие с Т-хелперами, изменяется в большей степени, чем численность В-клеток.

Во время внутриутробного периода развития фиксируется снижение содержания материнских антител. Клинические признаки заболевания появляются в возрасте двух-трех лет. Чувствительность к токсинам и внеклеточным бактериям снижается. Реакция иммунитета на большинство вирусов не меняется. Исключение, в частности, составляют вирусы Коксаки и Экхо. Увеличения лимфоузлов не наблюдается. При пальпации они мягкоэластической консистенции, не спаяны с другими тканями, безболезненны. Размер печени и селезенки не увеличен. Часто встречаются респираторные аллергозы, отит, экзема, бактериальные конъюнктивиты, пиодермии. Из-за недостаточности секреторных IgA может развиться синдром мальабсорбции. Осложнениями заболевания являются ревматоидный артрит, остеомиелит, которые могут перейти в сепсис $[1,5,10,14,15]$.

Диагноз подтверждается результатами лабораторных исследований: снижение количества В-лимфоцитов, иммуноглобулинов всех классов, в частности IgG, а также титром антител. Показатели Т-клеточного звена иммунитета остаются без изменений.

В качестве терапии назначают анибактериальные препараты, введение иммуноглобулинов (Иммуновенин, Пентаглобин, Сандоглобулин).

Прогноз, как правило, неблагоприятный.

\section{Клинический случай}

В республиканской детской клинической больнице г. Владикавказа в течение пяти лет наблюдался пациент с первичным иммунодефицитом гуморального звена иммунитета - болезнью Брутона. Помимо основного заболевания выявлены хронический рецидивирующий ювенильный артрит, пауциартикулярный вариант (активность первой степени, функциональное нарушение первой степени, рентгенологическое прогрессирование нулевой стадии), хронический гнойный средний отит, аденоиды третьей степени, анемия железодефицитная легкой степени.

Из анамнеза: родился от второй беременности, вторых срочных родов. Масса тела при рождении - 3 кг. Развивается в соответствии с возрастом. Перенес двустороннюю нижнедолевую пневмонию, правостороннюю верхнедолевую пневмонию (дважды), гнойный средний отит. Не привит.

В октябре 2014 г. поступил в хирургическое отделение республиканской детской клинической больницы с жалобами на отеки и боли в области голеностопных и коленных суставов, правого локтевого сустава, повышение температуры до $39{ }^{\circ} \mathrm{C}$. По результатам обследования поставлен диагноз: сепсис, септикопиемическая форма, острый гематогенный остеомиелит обеих бедренных костей, обеих большеберцовых костей, правой плечевой кости, гипохромная анемия средней степени.

В марте 2015 г. пациент неоднократно был госпитализирован в хирургическое отделение. Поставлен диагноз: хронический остеомиелит левого бедра, левосторонний гнойный гонит, двусторонний острый средний отит. Проведена антибактериальная терапия.

В апреле 2015 г. впервые обследован в отделении гематологии/ ревматологии республиканской детской клинической больни- цы г. Владикавказа. Диагноз: ювенильный идиопатический артрит, серонегативный (активность второй степени, функциональное нарушение второй степени, рентгенологическое прогрессирование второй стадии). По результатам обследования поставлен диагноз: первичный иммунодефицит гуморального звена иммунитета болезнь Брутона (агаммаглобулинемия), рецидивирующий гнойный средний правосторонний отит, хронический рецидивирующий ювенильный артрит, пауциартикулярный вариант (активность первой степени, функциональное нарушение первой степени, рентгенологическое прогрессирование нулевой стадии). Получал заместительную терапию внутривенными иммуноглобулинами (ВВИГ), нестероидные противовоспалительные препараты (Найз), метотрексат 5 мг один раз в неделю внутримышечно, преднизолон 15 мг с постепенной отменой, дипроспан в область коленного сустава и обоих голеностопных суставов. Через неделю после второго введения ВВИГ на фоне отмены глюкокортикостероидов зафиксировано выраженное обострение полиартрита с симметричным поражением суставов верхних и нижних конечностей. Повторно был назначен преднизолон, продолжено введение метотрексата.

В декабре 2015 г. в связи с персистированием артрита после снижения дозы и отмены глюкокортикостероидов назначен биологический препарат адалимумаб (Хумира) в дозе 40 мг один раз в две недели подкожно. Из-за повышения уровня трансаминаз, а также из-за рецидивирующего артрита метотрексат был отменен.

Последнее введение ВВИГ 18 января 2017 г. в отделении республиканской детской клинической больницы.

За прошедший период неоднократно переболел вирусными инфекциями, отмечались обост- 
рения отита, герпетические высыпания.

Из-за ухудшения состояния направлен участковым педиатром на обследование и лечение в республиканскую детскую клиническую больницу.

При поступлении обнаружена флегмона правой голени (в области икроножной мышцы), в связи с чем 1 июня 2017 г. проведена операция - вскрытие, санация, дренирование гнойника. С 1 по 9 июня 2017 г. находился на лечении в хирургическом отделении. Получал антибиотики, дезинтоксикационную терапию, ВВИГ (Иммуновенин) в дозе 10 г (2 и 3 июня).

Для дальнейшего обследования и лечения переведен в отделение гематологии/ревматологии.

В декабре 2018 г. ребенок направлен на стационарное лечение в республиканскую детскую клиническую больницу.

При поступлении масса тела - 15 кг, рост - 100 см. Нормального телосложения. Удовлетворительного питания.

Состояние средней тяжести. Кожные покровы бледно-розовые, единичные экхимозы на нижних конечностях. Периферические лимфоузлы единичные до 1 см. Дефигурация коленных суставов (в большей степени правого), умеренная болезненность при активных движениях.

Дыхание пуэрильное. Частота дыхания - 24 в минуту.

Область сердца на вид не изменена. Границы относительной сердечной тупости: правая - на 1 см снаружи от правого края грудины, левая - на 1 см снаружи от левой срединно-ключичной линии. Тоны сердца средней громкости, ритм не нарушен, короткий систолический шум на верхушке. Частота сердечных сокращений - 96 в минуту. Артериальное давление 90/50 мм рт. ст.

Живот мягкий, безболезненный, печень и селезенка не увеличены. Стул и диурез не нарушены.

Результаты лабораторных анализов от 20 мая 2019 г. Общий анализ крови: уровень эритроцитов $-4,75 \times 10^{12}$, гемоглобина 110 г/л, тромбоцитов - $332 \times 10^{9}$, ретикулоцитов - $13 \%$, лейкоцитов - $8,5 \times 10^{9}$, палочкоядерных нейтрофилов - 5\%, эозинофилов - 9\%, сегментоядерных нейтрофилов - 20\%, лимфоцитов $59 \%$, моноцитов - 7\%, скорость оседания эритроцитов - 4 мм/ч. Биохимический анализ крови: С-реактивный белок - отрицательно, IgA - 28 мг/дл (норма 80-406 мг/дл), IgM - 12 мг/дл (34-214 мг/дл), IgG - 813 мг/дл (680-1650 мг/дл), общий белок 65 г/л, альбумин - 46 г/л, общий билирубин - 9,8 мкм/л, прямой - 1,9 мкм/л, сывороточное железо - 11,3 мкм/л, лактатдегидрогеназа - 872 ед/л, щелочная фосфатаза - 219 ед/л, мочевина $4,8 \mathrm{mм} / л$, креатинин - 46 мкм/л, глюкоза - 4,4 мм/л, холестерин 3,1 $\mathrm{Mм} /$ л.

Общий анализ мочи от 20 мая 2019 г.: без патологии.

Результаты электрокардиограммы от 29 ноября 2018 г.: синусовый ритм, частота сердечных сокращений - 109 в минуту, горизонтальное положение электрической оси сердца.

Рентгенограмма органов грудной клетки от 21 мая 2019 г.: легочные поля прозрачны, тени корней не расширены, структура прослеживается, синусы свободные, тень средостения без особенностей.

Ультразвуковое исследование органов брюшной полости от 21 мая 2019 г.: печень на 1,5 см ниже реберной дуги, контур ровный четкий, эхоструктура паренхимы однородная, сосудистый рисунок сохранен, желчный пузырь $58 \times 17$ мм (норма $44 \times 16$ мм), деформирован, стенки тонкие, содержимое однородное, поджелудочная железа, селезенка, почки в норме.

Консультации врачей-специалистов: ЛОР от 28 мая 2019 г.: аденоиды третьей степени. Рекомендована аденотомия.

Исследован иммунный статус. Показатели клеточного иммунитета: CD3 - 50\%, CD4 - 34,0\%, CD8 - 27,0\%, CD25 - 2,1\%, co- отношение CD4/CD8 - 1,24\%, CD16 - 15,2\%, CD18 - 68,3\%, CD26 - 21,1\%, CD45RA - 58,2\%, CD95 - 35,2\%, HLA-1 - 85,2\%, HLA-DR - 10,3\%, CD11b - 4,9\%.

Показатели гуморального иммунитета в динамике: IgG - 1,2 г/л,

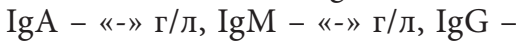
2,1 г/л, $\operatorname{Ig} \mathrm{A}$ - «-» г/л, $\operatorname{Ig} \mathrm{M}$ - «-» г/л, $\operatorname{IgG}-0,2$ г/л, $\operatorname{Ig} \mathrm{A}-$ «-» г/л, $\operatorname{Ig} M-$ «-»г/л.

Факторы неспецифической резистентности: фагоцитарный индекс - 30\%, фагоцитарное число - 2,8 ед., тест с нитросиним тетразолем - 6\%, средний цитохимический индекс - 0,05, активность лизоцима - $20 \%$, циркулирующие иммунные комплексы - 18 ед.

Рекомендовано: наблюдение педиатра, гематолога, иммунолога, ревматолога, отоларинголога. Аденотомия в плановом порядке. Проведение биохимического анализа крови один раз в три месяца плюс определение уровня аланинаминотрансферазы один раз в месяц. Внутривенное введение иммуноглобулина 10 г один раз в четыре недели. Подкожное введение препарата Хумира 40 мг один раз в две недели, метотрексата 5 мг один раз в неделю. Применение фолиевой кислоты 1 мг один раз в день, кроме дня введения метотрексата, Мальтофера в виде сиропа 10 мл один раз в день. Отвод от профилактических прививок.

Ребенок должен быть внесен в регистр страдающих орфанными заболеваниями.

В настоящий момент времени пациент находится на диспансерном наблюдении в поликлинике по месту жительства у педиатра, иммунолога и ревматолога. В случае необходимости может быть госпитализирован в республиканскую детскую клиническую больницу г. Владикавказа.

\section{Заключение}

Болезнь Брутона - редкое заболевание, относящееся к группе первичных иммунодефицитных состояний. Недостаточная информированность педиатров о данной патологии приводит к несвоевре- 
менности диагностики и проведения адекватной терапии.

Приведенные нами данные могут способствовать повышению качества оказания ме- дицинских услуг в условиях стационара и амбулаторно-поликлинического звена. Более ранняя диагностика и своевременно начатое лечение приведут к сни-

\author{
жению частоты летальных \\ исходов. \\ Авторь заявляют \\ об отсутствии конбликта \\ интересов.
}

\section{Литература}

1. Chun J.K., Lee T.J., Song J.W. et al. Analysis of clinical presentations of Bruton disease: a review of 20 years of accumulated data from pediatric patients at Severance Hospital // Yonsei Med. J. 2008. Vol. 49. № 1. P. 28-36.

2. Ярилин А.А. Основы иммунологии. М.: Медицина, 1999. C. 607-608.

3. Amoras A.L., da Silva M.T., Zollner R.L. et al. Expression of Fc gamma and complement receptors in monocytes of $\mathrm{X}$-linked agammaglobulinaemia and common variable immunodeficiency patients // Clin. Exp. Immunol. 2007. Vol. 150. № 3. P. 422-428.

4. Ferrari S., Lougaris V., Caraffi S. et al. Mutations of the Igbeta gene cause agammaglobulinemia in man // J. Exp. Med. 2007. Vol. 204. № 9. P. 2047-2051.

5. Wahn U., Seger R., Wahn V. Padiatrische allergologie und immunologie in klinik und praxis. Gustav Fisher VerlagStutgard-Jena-New York, 1994. Vol. 1. P. 579-581.

6. JoyceE.Yu.,Jordan S.O., Yesim Y.D. Primary immunodeficiency diseases: current conditions and prospects // Speransky J. Pediatria. 2019. Vol. 98. № 3. P. 8-23.

7. Маиук О.Н., Асирян Е.Г., Матюшенко О.В. Иммунодефицитные состояния у детей. Клинический случай первичного комбинированного Т-клеточного иммунодефицита // Достижения фундаментальной, клинической медицины и фармации. Материалы 72-й научной сессии ВГМУ. 2017. С. 269-270.

8. Молотилов Б.А. Первичные иммунодефицитные состояния: актуальные вопросы диагностики и лечения //
Актуальные вопросы диагностики, лечения и реабилитации больных. Материалы XIX юбилейной межрегиональной научно-практической конференции, посвященной 40-летию ПИУВ - филиала ФГБОУ ДПО РМАНПО Минздрава России. 2017. С. 310-312.

9. Щербина А.Ю., Косачева Т.Г., Румяниев А.Г. Первичные иммунодефицитные состояния: вопросы диагностики и лечения // Вопросы гематологии/онкологии и иммунопатологии в педиатрии. 2010. Т. 9. № 2. С. 23-31.

10. Nelson textbook of pediatrics. W.B. Saunders Company, 1992.

11. Conley M.E., Howard V. Clinical findings leading to the diagnosis of X-linked agammaglobulinemia // J. Pediatr. 2002. Vol. 141. № 4. P. 566-571.

12. Бочарова К.А. Современные аспекты диагностики первичных иммунодефицитных состояний // Научные ведомости Белгородского государственного университета. Серия: Медицина. Фармация. 2010. № 22 (93). Выпуск 12. С. 14-24.

13. Вельтищев Ю.Е. Иммунная недостаточность у детей // Российский вестник перинатологии и педиатрии. 2004. Т. 49. № 4. С. 3-9.

14. Галаева И.Ю. Клинические маски болезни Брутона. Сложности постановки диагноза, особенности терапии // Пятая итоговая научная сессия молодых ученых РостГМУ. Сборник материалов. 2018. С. 37-39.

15. Коченгина С.А., Масленникова Н.П., Моисеева Т.Н., Курочкина М.В. Первичные (врожденные) иммунодефицитные состояния у детей. Опыт клинико-лабораторной диагностики в ЧОДКБ // Педиатрический вестник Южного Урала. 2013. № 2. С. 82-85.

\section{Primary Immunodeficiency of Humoral Immunity - Bruton's Disease in a Six-Year-Old Child (Clinical Case)}

T.B. Kasokhov, MD, PhD, Prof., ${ }^{1,2}$, Z.A. Tsorayeva, $\mathrm{PhD}^{1}$, A.I. Mazur' ${ }^{1}$, S.V. Turiyeva, $\mathrm{PhD}^{1}$, A.A. Tsareva ${ }^{1}$, A.V. Alborova $^{1}$, A.Z. Ramonova ${ }^{1}$

${ }^{1}$ North Ossetia State Medical Academy

${ }^{2}$ Institute of Biomedical Reserches of VSC RAS, RNO - Alania, Vladikavkaz

Contact person: Timofey B. Kasokhov, kasohov@mail.ru

Primary immunodeficiency is a significant problem for modern health care. At the initiative of a number of countries, the European register of patients with primary hereditary immunodeficiency states and gene mutations as the causes of primary immune deficiency was established. The disease is more common in boys than in girls, but in late manifestations and adults are detected with almost equal frequency for both sexes. Agammaglobulinemia (Bruton's disease) is a very rare X-linked hereditary disease (frequency 1:1,000,000 newborn boys), but of interest as a classical model of isolated humoral immunity deficiency. It is associated with a mutation of the cytoplasmic tyrosine kinase gene (VTK gene), which provides the process of differentiation of pre-B lymphocytes. The disease is characterized by an aggressive course, in the absence of adequate therapy, a lethal outcome is possible. The article presents a clinical case of Bruton's disease in a 6-year-old boy.

Key words: Bruton's disease, immunity, immunodeficiency, immunoglobulins, humoral link 